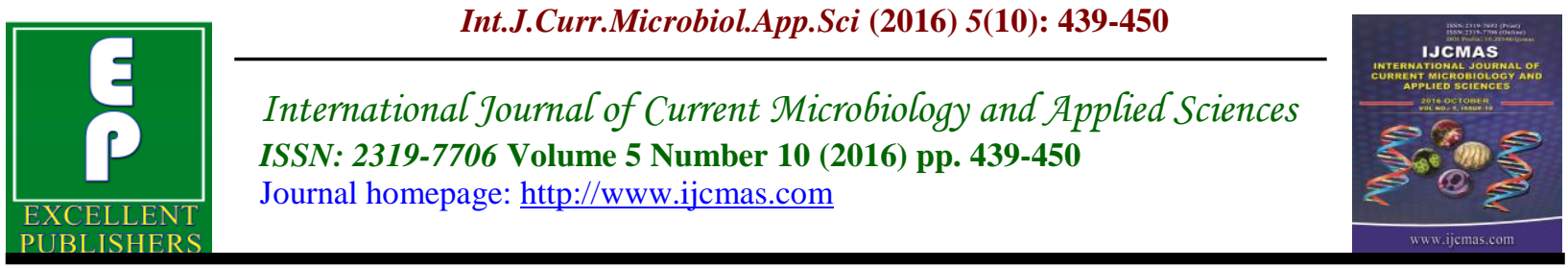

Original Research Article

http://dx.doi.org/10.20546/ijcmas.2016.510.050

\title{
Water Quality Analysis of Lake Siliserh, India
}

\author{
J. Vashistha, P.J. John* and P.V. Paulose \\ Environmental Toxicology Laboratory, Department of Zoology, University of Rajasthan, \\ Jaipur-302004, Rajasthan, India \\ *Corresponding author
}

\section{Keywords}

Lake Siliserh, Physio-chemical, Correlation, Oligotrophic, Eutrophic.

\section{Article Info}

Accepted:

16 September 2016

Available Online:

10 October 2016

\section{A B S T R A C T}

Water quality of Siliserh lake was studied for period of one year on the basis of monthly sampling. Correlation between various physiochemical parameters were also calculated according to KarlPearson's formula. This study has provided the first data set for water quality of lake. The value of various physico-chemical parameter were temperature $\left(9^{0} \mathrm{C}\right.$ to $\left.31^{\circ} \mathrm{C}\right), \mathrm{pH}(7.1$ to 8.3$)$, electrical conductivity (127.0 $\mu$ mhos $\mathrm{cm}^{-1}$ to $454.2 \mu$ mhos $\mathrm{cm}^{-1}$, dissolved oxygen $\left(4.5 \mathrm{mgL}^{-1}\right.$ to 12.5 $\left.\mathrm{mgL}^{-1}\right)$, free $\mathrm{CO} 2\left(3.08 \mathrm{mgL}^{-1}\right.$ to $\left.12.32 \mathrm{mgL}^{-1}\right)$, alkalinity $\left(70 \mathrm{mgL}^{-1}\right.$ to $161.6 \mathrm{mgL}^{-}$ $\left.{ }^{1}\right)$, acidity $\left(2.4 \mathrm{mgL}^{-1}\right.$ to $\left.68.0 \mathrm{mgL}^{-1}\right)$, Hardness $\left(56.8 \mathrm{mgL}^{-1}\right.$ to $\left.148.6 \mathrm{mgL}^{-1}\right)$, total dissolved solid (127.4 to $\left.782.2 \mathrm{mgL}^{-1}\right)$, total suspended solids $\left(24.0 \mathrm{mgL}^{-1}\right.$ to 371.2 $\left.\mathrm{mgL}^{-1}\right)$, salinity $\left(82.0 \mathrm{mgL}^{-1}\right.$ to $\left.421.4 \mathrm{mgL}^{-1}\right)$, nitrate $\left(1.0 \mathrm{mgL}^{-1}\right.$ to $5.78 \mathrm{mgL}^{-1}$ ), phosphate $\left(0.004 \mathrm{mgL}^{-1}\right.$ to $\left.0.022 \mathrm{mgL}^{-1}\right)$, biological oxygen demand $\left(2.04 \mathrm{mgL}^{-1}\right.$ to $\left.8.98 \mathrm{mgL}^{-1}\right)$, chemical oxygen demand $\left(4.4 \mathrm{mgL}^{-1}\right.$ to $\left.9.08 \mathrm{mgL}^{-1}\right)$ and sulphate (3.9 $\mathrm{mgL}^{-1}-21.0 \mathrm{mgL}^{-1}$ ).Dissolved $\mathrm{O} 2$ showed positive correlation with $\mathrm{Ca}$ hardness and negative correlation with temperature, TDS, TS, acidity, nitrate and sulphate. TDS showed a positive correlation with TS and sulphate. All the physicochemical factors studied except BOD studied were found within the permissible limit for drinking water as recommended by Bureau of Indian Standard (BIS). The lake was found to be slightly eutrophic during monsoon months. Main reason was nutrients and other organic matter from the agriculture fields in the catchment area are brought to the lake due to influx of rain water.

\section{Introduction}

The whole economy of any lakes depends on the physico-chemical properties of water (Hutchinson, 1967). Various physicochemical characteristics of different water bodies identify the factor operating upon aquatic ecosystem which indicates not only the condition of water but also express the nature of biological component. All metabolic and physiological activities of life such as feeding, reproduction, movement, and distribution of aquatic organisms are greatly influenced by physico-chemical parameters of a water body. Temperature, free $\mathrm{CO}_{2}$, bicarbonate, calcium and magnesium hardness, biological oxygen demand, chemical oxygen demand, dissolved oxygen, dissolved solids and EC are related to the biological productivity (Sharma, 1980; Birge and Juday, 1911). 
Thus, these physico-chemical characters are used for assessment of trophic status and ecological nature of the water body (Meena and Sharma, 2004).

Rajasthan is the largest state of the country. There are quite a few fresh water lakes in Rajasthan. Most of them are heavily polluted and are facing an imminent danger of irreparable degeneration. Anthropogenic activities are the main causative agents in the increase of nutrients like phosphates, chlorides and calcium and ultimately lead to eutrophication (Chukwu and Odunzeh, 2006; Shashi Shekhar et al., 2008). Due to unplanned management, tremendous development of industry and agriculture and disposal of untreated public sewage water, agricultural runoff and other human and animal wastes in to river, lakes, reservoirs and other water bodies are continuously deteriorating their water quality and biotic resources (Venkatesan, 2007; Elmaci et al., 2008).

Siliserh Lake is an important water body of Rajasthan state. This Lake is a major source of potable water for the population of Alwar city of Rajasthan. Every year, about 4.814 MCM of water is discharged from the lake for irrigation and used in culturable command area of $7.2 \mathrm{~km}^{2}$. Besides, this lake also has appreciable fish productivity potential. Total catch of fish from this lake was 1363.3 MT in the year 2010-11 in 2.7 $\mathrm{km}^{2}$ of productive area. It is also a source of aesthetic pleasure and holiday recreation for tourists and local people by providing boating facilities. The lake also attracts a lot of migratory birds. But there is no report available on the water quality of this Lake. Some silent features of Lake are given in table 1.The judicious management and proper utilization of water of this lake require a systematic study of its ecology. Adequate information about the various physico-chemical components influencing parameters and the delicate dynamics sustained by them is of supreme importance to formulate appropriate environmental management strategies and to protect the lake from degradation. The study of physico-chemical factors could be of great help in successful fishery management also.

So, the Siliserh Lake was studied for various physico-chemical aspects such as temperature, transparency, $\mathrm{pH}$, Electrical Conductivity (EC), dissolved oxygen, free carbondioxide, alkalinity, acidity, calcium hardness, magnesium hardness, total hardness, biological oxygen demand (BOD), chemical oxygen demand (COD), total dissolved solids (TDS), total solids (TS), total suspended solids (TSS), nitrate, phosphate and sulphate of water.

\section{Methodology}

Limnological studies were carried out for a period of one year from July, 2010 to June, 2011. The water and plankton samples were collected on monthly basis from five different locations including areas of maximum and minimum human activities (Fig. 1). For physico-chemical studies, water samples were collected in $500 \mathrm{ml}$ plastic bottles, brought to laboratory for further analysis. Various physico-chemical parameters were estimated according to APHA (2005). Nitrate (inorganic), phosphate (ortho) and sulphate were estimated by the spectrophotometric method. The Correlation between various physico-chemical parameters were tested using Karl Pearson's Correlation formula (Pearson Product Moment Correlation Coefficient) as follows:

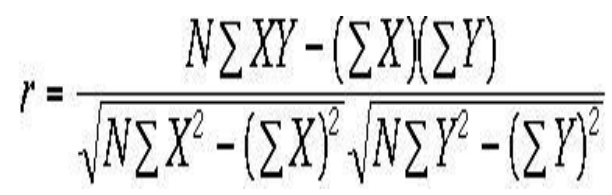


Where,

$\mathrm{N}=$ Number of observation

$\mathrm{X}=$ Variables of series $\mathrm{X}$
$\mathrm{Y}=$ Variables of series $\mathrm{Y}$

The statistical calculations were based on

Ipsen \& Feigl (1970) method.

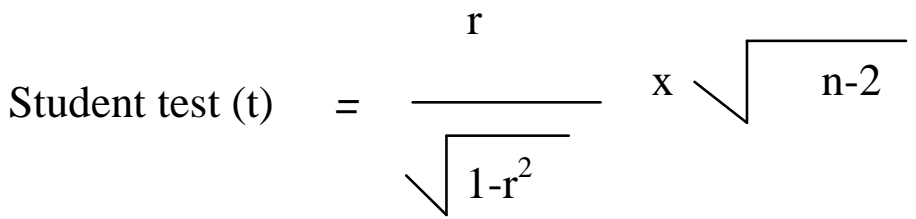

Where,

Siliserh Lake. The temperature variation is one of the factors in the lake ecosystem, which may influence other physico-chemical characteristics and also influence the distribution and abundance of flora and fauna (Soundarapandian et al., 2009). A rise in temperature of the water leads to an increase in the rate of chemical reaction in water besides reducing the solubility of gases.

In the present study, water temperature varied between $9^{0} \mathrm{C}$ and $31^{\circ} \mathrm{C}$, with high values during summer months and low during winter months at all stations associated with longer photoperiods, bright sunshine and dry wind. As ambient temperature increases in summer, lake water also warms up. The air temperature was always higher than the water temperature and the difference between the two was, in general, highest in summer and lowest in winter. The observed low value of temperature in winter was due to lower solar radiation and cold breeze. The recorded high value during summer could be attributed to high solar radiation (Surve et al., 2005; Haroon et al., 2010 and Manikannan et al., 2011).

The $\mathrm{pH}$ of water was always on the alkaline side; it ranged from 7.1 to 8.3. It was relatively high in the summer and low in winter months. The high $\mathrm{pH}$ during summer 
may probably be due to high biological activity (Das et al., 1997) including photosynthesis (Subramanian and Mahadevan, 1999). Alkaline water can support higher productivity (Khan and Khan, 1985) and can support good fishery also (Toor and Gill, 1974). Most of the natural waters are generally alkaline due to the presence of sufficient quantity of carbonates (Trivedi and Goel, 1992). Seasonal variations in $\mathrm{pH}$ may be attributed to various factors like removal of $\mathrm{CO}_{2}$ for photosynthesis, dilution of lake water by rain water influx, primary productivity, salinity and temperature changes and decomposition of organic matter (Tamot et al., 2007).

The EC was found to fluctuate between 127 $\mu$ mhos $\mathrm{cm}^{-1}$ (October 2010) to $454.2 \mu$ mhos $\mathrm{cm}^{-1}$ (April 2011) in Siliserh Lake. EC showed increasing trend with the advent of summer (Maulood et al., 1979). It is generally low during monsoon and rises during summer and it also showed positive correlation with temperature. EC depends upon temperature of the water (Horne and Goldman, 1994). As water temperature increases, EC also increases because warmer conditions enhance evaporation of lake water resulting an increase in electrolytes. The fluctuations in the values of EC observed during the present study could also be due to variations in the rate of decomposition of organic matter. Decomposition of organic matter releases dissolved substance and nutrients whereas continuous evaporation leads to an increase in electrolytes. Both of these factors can increase EC of water (Parray et al., 2010).

The dissolved oxygen content was observed in the range of $4.5-12.5 \mathrm{mgL}^{-1}$. The maximum value of dissolved oxygen (DO) was observed in winter months while minimum in the monsoon months. The DO in water is a very important parameter as it serves as an indicator of the physical, chemical and biological activities of water body. Two main sources of dissolved oxygen are diffusion of oxygen from the air and photosynthetic activity (Khan et al., 2012).

In the present study DO was found negatively correlated with temperature. The values had tendency to show a gradual decline from winter to summer in the lake studied substantiating the generally accepted view that DO is inversely proportional to temperature. The high values of DO during winter can be ascribed to its higher solubility at low temperature. It is well known that the temperature affect the dissolution of oxygen (Vijayakumar et al., 2000). A slight decrease in DO during monsoon may be due to vertical mixing which brought hypolimnetic deposits to the water surface resulting turbidity and reduced oxygen concentration (Araoye, 2007). An inverse relationship between dissolved oxygen and free $\mathrm{CO}_{2}$ was found in the present study as DO is mainly regulated by photosynthetic activity of algal flora when free $\mathrm{CO}_{2}$ is utilized (Hosmani and Bharti, 1980).

In the present investigation, the values of free CO2 varied from 3.08 to $12.32 \mathrm{mgL}^{-1}$. Carbon dioxide is the basis of the entire carbon chain. Free $\mathrm{CO}_{2}$ is liberated during respiration of aquatic organisms and decay of organic matter. Free $\mathrm{CO}_{2}$ was present during whole year at all sites studied but the values were maximum in summer and minimum in winter season. The high values during summer may be attributed to accelerated rate of decomposition of organic matter by microbes in the mud (Singh, 1987). The carbon dioxide content of water also depends upon the water temperature, depth, rate of respiration, decomposition of 
organic matter, chemical nature of the bottom and geographical features of the surrounding water body (Sakhere and Joshi, 2002). Photosynthesis and respiration are the two major factors that influence the amount of free $\mathrm{CO}_{2}$ concentration in water (Sreenivasan, 1970).

The total alkalinity was found lowest in July (70.0 $\mathrm{mgL}^{-1}$ ) and in subsequent months, it was continuously increasing and reached $161.1 \mathrm{mgL}^{-1}$ in May. This range of alkalinity makes the reservoir as nutrient rich and highly productive water body (Munawar, 1970). The increase in alkalinity in summer season can be attributed to decrease in water volume due to increased rate of evaporation at high temperature which also coincides with higher concentration of nutrients and bicarbonates (Hazelwood and Parker, 1961). Lower values of alkalinity in monsoon months may be attributed to dilution of lake water due to rainfall (Das and Chand, 2003).

During the study period, the value of acidity ranged from $12.4 \mathrm{mgL}^{-1}$ to $68.0 \mathrm{mgL}^{-1}$ in March 2011 and October 2010 respectively. Hardness ranged between the lowest value of $56.8 \mathrm{mgL}^{-1}$ and the highest value of 148.6 $\mathrm{mgL}^{-1}$ during October and May respectively. The maximum value of hardness was observed in summer months while minimum in the monsoon months. The TDS range in Siliserh Lake was between 127.4 and 782.2 $\mathrm{mgL}^{-1}$ whereas TSS varied between 24 and $371.2 \mathrm{mgL}^{-1}$. Maximum TS were recorded in the month of September (996.8 $\mathrm{mgL}^{-1}$ ). Total hardness in water is the sum of concentration of alkaline earth metal cation such as $\mathrm{Ca}^{++}, \mathrm{Mg}^{++}$. The total hardness is the total soluble magnesium and calcium salts present in the water expressed as its $\mathrm{CaCO}_{3}$ equivalent. In most natural waters the predominant ions are bicarbonates, associated mainly with calcium and than with magnesium. Hardness decreased in monsoon and increased in summer. Increased hardness in summer may be due to excessive evaporation (Jana, 1973). Low hardness in monsoon may be attributed to the dilution by rain water coming from the vast catchment area $\left(10.25 \mathrm{~km}^{2}\right)$ of lake.

According to this classification, Siliserh Lake falls in the category of hard water body. In aquatic environment calcium serves as one of the micronutrients for most of the organisms. Calcium hardness was maximum in summer months which may be due to rapid oxidation of organic matter containing calcium (Sundar, 1988). Magnesium is often associated with calcium in all kinds of waters, but its concentration remains generally lower than the calcium (Venkatasubramani and Meenambal, 2007). $\mathrm{Mg}$ level reached upto $18.11 \mathrm{mgL}^{-1}$ in May. The salinity range was between 82.0-421.4 $\mathrm{mgL}^{-1}$ and maximum value was reported in the month of November. Salinity is one of the important factors which profoundly influence the abundance, distribution, functional physiology and reproductive activity of the animals in lake water (Kinne, 1971). The low values found during monsoon may be due to heavy rainfall and large quantity of freshwater inflow in to the lake (Soundarapandian et al., 2009 and Damotharan et al., 2010).

Nitrate and phosphate content ranged between 1.0 to $5.78 \mathrm{mgL}^{-1}$ and 0.004 to $0.022 \mathrm{mgL}^{-1}$ respectively. Nitrates are the most oxidized forms of nitrogen and the end product of the aerobic decomposition of organic nitrogenous matter. Higher values of nitrate concentration recorded during monsoon season may be due to anthropogenic input and organic matter from the catchments area. Natural waters in their unpolluted state contain only minute quantities of nitrate. Nitrate is a major ingredient of farm fertilizer and is necessary 
for crop production. When rains, varying nitrate amounts wash from farmland into nearby waterways. Another possible way of nitrate input might be through oxidation of ammonia in the form of nitrogen to nitrite and consequently to nitrate (Rajasegar, 2003 and Tepe et al., 2005). The recorded low values during winter may be due to slow decomposition of organic matter at low temperature combined by uptake of nitrate by phytoplankton (Gouda and Panigrahy, 1996).

Phosphate is the most important ecological factor for the growth and distribution of flora and fauna in any aquatic ecosystem. The dissolved phosphate concentration ranged from $0.004 \mathrm{mgL}^{-1}$ to $0.022 \mathrm{mgL}^{-1}$ in the investigated water body.

The recorded highest phosphate values during monsoon season could be attributed to heavy rainfall, surface runoff receiving cattle dung, detergents, and agricultural fertilizers from surrounding catchment area. The rainfall reported in the catchment area during the year 2010 and 2011 was $928 \mathrm{~mm}$ and $650 \mathrm{~mm}$ respectively.

In addition to fertilizers like superphosphate applied to the agricultural fields and alkyl phosphates used in households as detergents can be the other sources of phosphate during monsoon. The variation may also be due to the process like adsorption and desorption of phosphate and buffering action of sediment under varying environmental conditions (Rajasegar, 2003). The low values observed during winter may be due to decreased runoff combined by utilization of phosphate by phytoplankton (Ramakrishnan et al., 1999). Further regeneration and release of total phosphorus from bottom mud into the water column by turbulence and mixing also attributed to higher monsoon values (Chandran and Ramamoorthy, 1984).
Biological oxygen demand (BOD) is the amount of oxygen utilized by microorganisms in stabilizing the organic matter. BOD in Siliserh Lake was in the range between $2.02 \mathrm{mgL}^{-1}$ and $8.98 \mathrm{mgL}^{-1}$ with low values in winter and high values in summer season (Garg et al., 2009). Chemical oxygen demand (COD) is a measure of the oxygen equivalent of the organic matter content of water that is susceptible to oxidation by a strong chemical oxidant. Thus, COD is reliable parameter for judging the extent of pollution in water (Amirkolaie, 2008). The ranges COD was 4.4 to $9.08 \mathrm{mgL}^{-1}$. In Siliserh Lake high COD values recorded during the dry season has been ascribed to the death and decay of plants and the consequent increase in organic matter. The COD of water increases with increasing concentration of organic matter (Kumar and Sharma, 2005). During the rainy season TS, TSS and TDS values were highest as compared to summer and winter seasons. This may be due to inflow of soil and fertilizers from the agricultural field in and around the catchments area.

The variations in sulphate level was between 3.9-21.0 mgL $\mathrm{m}^{-1}$. Sulphates are found in appreciable quantities in all natural waters. They are particularly high in arid and semiarid waters where salt content is more (Rajasegar, 2003). Salts of sulphate are mostly soluble in water and impart hardness. The lake under study showed a moderate sulphate concentration that ranged from 3.9 to $21.0 \mathrm{mgL}^{-1}$. A peak value in sulphate content was observed during monsoon months and it may be due to incoming runoff water of monsoon rains.

In conclusion, all the physico-chemical factors except BOD, studied were found within the permissible limit for drinking water as recommended by BIS. 
Table.1 Salient features of Siliserh Lake.

\begin{tabular}{|l|l|l|}
\hline 1. & River basin & Ruparail \\
\hline 2. & Catchment area & $11.25 \mathrm{sq} \mathrm{Km}$ \\
\hline 3. & Average annual rainfall & $675.30 \mathrm{~mm}$ \\
\hline 4. & Gross command area & $10.34 \mathrm{sq} \mathrm{Km}$ \\
\hline 5. & Culturable command area (CCA) & $7.2 \mathrm{sq} \mathrm{Km}$ \\
\hline 7. & Design maximum flood & $475.72 \mathrm{~m}^{3} / \mathrm{s}$ \\
\hline 8. & Top bank level (TBL) & $10.03 \mathrm{~m}$ \\
\hline 9. & Maximum water level (MWL) & $9.75 \mathrm{~m}$ \\
\hline 10. & Full tank Level (FTL) & $9.29 \mathrm{~m}$ \\
\hline 11. & Full reservoir level & $13.93 \mathrm{MCM}$ \\
\hline 12. & Type of dam & Earthen \\
\hline 13. & Length of dam & $304 \mathrm{~m}$ \\
\hline 14. & Length of overflow portion & $30 \mathrm{~m}$ \\
\hline 15. & Free boards & $0.92 \mathrm{~m}$ \\
\hline 16. & Dead storage & $0.78 \mathrm{~m}$ \\
\hline 17. & Year of construction & 1845 \\
\hline
\end{tabular}

Fig.1 Satellite map of Lake Siliserh showing all five sites studied.

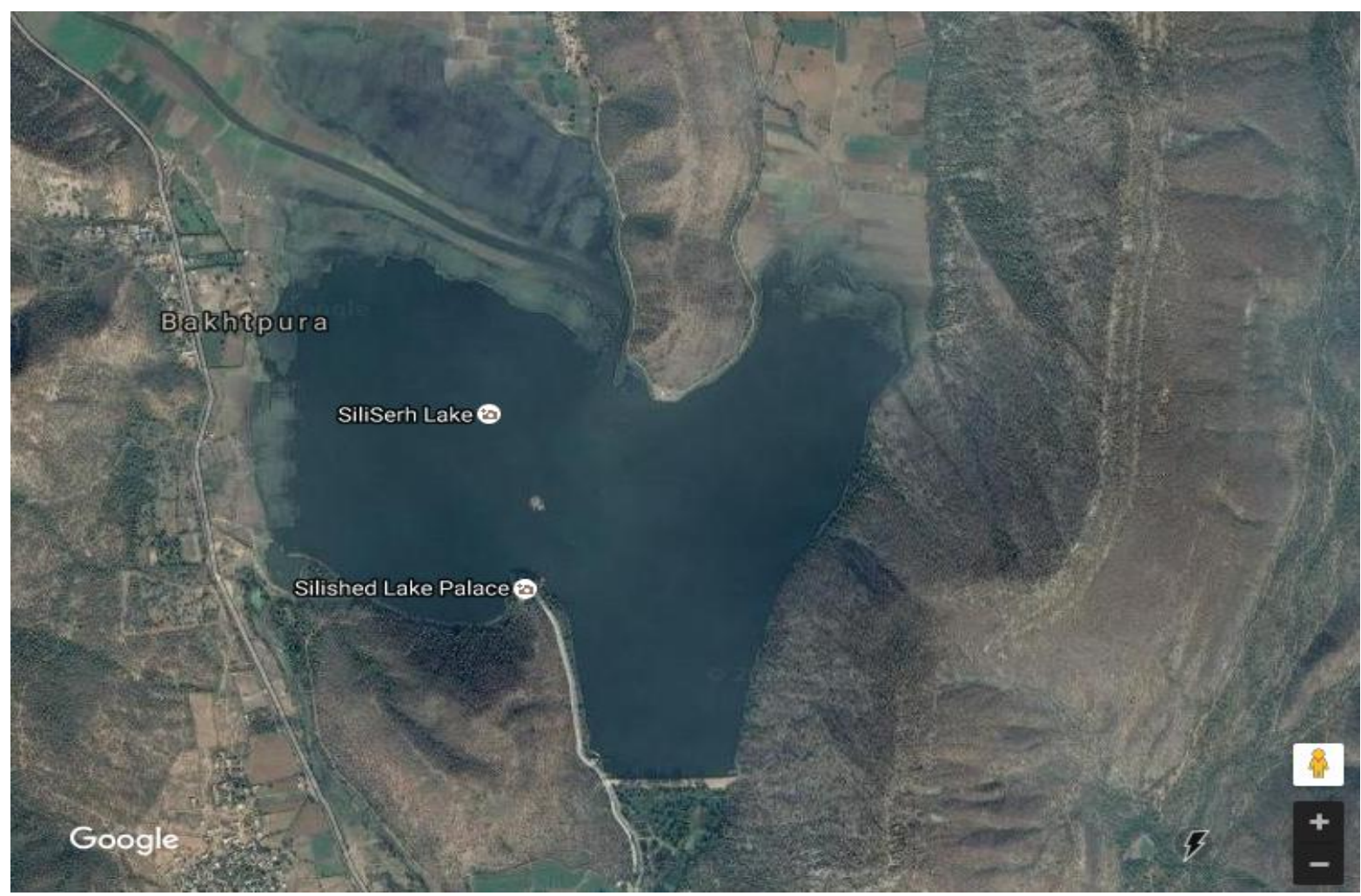


Table.2 Mean monthly values of various physico-chemical parameters at five stations in Siliserh Lake.

\begin{tabular}{|c|c|c|c|c|c|c|c|c|c|c|c|c|}
\hline Parameters & July & Aug. & Sep. & Oct. & Nov. & Dec. & Jan. & Feb. & March & April & May & June \\
\hline Air Temperature $\left({ }^{0} \mathrm{C}\right)$ & $35.0 \pm 0.01$ & $32.0 \pm 0.02$ & $31.0 \pm 0.02$ & $30.0 \pm 0.01$ & $28.0 \pm 0.01$ & $20.0 \pm 0.01$ & $11.0 \pm 0.01$ & $15.0 \pm 0.11$ & $21.0 \pm 0.09$ & $30.0 \pm 0.11$ & $33.0 \pm 0.34$ & $36.0 \pm 0.03$ \\
\hline Water Temperature $\left({ }^{\circ} \mathrm{C}\right)$ & $30.0 \pm 0.06$ & $28.0 \pm 0.01$ & $29.0 \pm 0.07$ & $28.0 \pm 0.07$ & $22.0 \pm 0.01$ & $13.0 \pm 0.08$ & $9.0 \pm 0.01$ & $11.0 \pm 0.61$ & $17.0 \pm 0.01$ & $24.0 \pm 0.01$ & $30.0 \pm 0.08$ & $31.0 \pm 0.03$ \\
\hline $\mathrm{pH}$ & $8.09 \pm 0.03$ & $7.68 \pm 0.12$ & $7.63 \pm 0.16$ & $7.11 \pm 0.22$ & $7.24 \pm 0.10$ & $7.78 \pm 0.06$ & $8.02 \pm 0.12$ & $8.26 \pm 0.06$ & $8.10 \pm 0.04$ & $8.16 \pm 0.12$ & $8.28 \pm 0.12$ & $8.37 \pm 0.13$ \\
\hline $\begin{array}{l}\text { Conductivity }\left(\mu \text { mhos } \mathrm{cm}^{-}\right. \\
\left.{ }^{1}\right)\end{array}$ & $180.2 \pm 0.01$ & $158.6 \pm 0.03$ & $388.4 \pm 0.33$ & $127 \pm 0.03$ & $142 \pm 0.03$ & $164.6 \pm 0.07$ & $196.2 \pm 0.06$ & $182 \pm 0.02$ & $251.2 \pm 0.24$ & $454.2 \pm 0.15$ & $337 \pm 0.09$ & $267.4 \pm 0.03$ \\
\hline Water Level (m) & $3.96 \pm 0.64$ & $4.78 \pm 0.63$ & $7.19 \pm 0.62$ & $6.97 \pm 0.69$ & $6.87 \pm 0.63$ & $6.81 \pm 0.68$ & $6.73 \pm 0.67$ & $6.18 \pm 0.75$ & $5.72 \pm 0.62$ & $5.44 \pm 0.62$ & $3.76 \pm 0.67$ & $3.22 \pm 0.62$ \\
\hline Dissolved $\mathrm{O}_{2}\left(\mathrm{mgL}^{-1}\right)$ & $6.0 \pm 0.33$ & $10.08 \pm .08$ & $7.76 \pm 0.92$ & $4.56 \pm 0.69$ & $10.08 \pm 1.50$ & $10.32 \pm 0.96$ & $11.5 \pm 0.69$ & $12.56 \pm 0.79$ & $11.68 \pm 0.74$ & $10.9 \pm 1.21$ & $9.76 \pm 0.10$ & $10.46 \pm 0.16$ \\
\hline Free $\mathrm{CO}_{2}\left(\mathrm{mgL}^{-1}\right)$ & $3.52 \pm 0.88$ & $4.4 \pm 1.07$ & $8.07 \pm 0.09$ & $10.56 \pm 1.07$ & $5.28 \pm 0.88$ & $8.8 \pm 0.0$ & $3.08 \pm 0.54$ & $6.16 \pm 1.07$ & $8.8 \pm 0.0$ & $12.32 \pm 0.48$ & $8.8 \pm 0.0$ & $4.4 \pm 0.0$ \\
\hline Alkalinity $\left(\mathrm{mgL}^{-1}\right)$ & $70.0 \pm 5.09$ & $107.0 \pm 5.56$ & $97.2 \pm 3.72$ & $104.0 \pm 5.09$ & $88.0 \pm 12.0$ & $144.0 \pm 6.0$ & $75.0 \pm 2.73$ & $153.0 \pm 3.0$ & $118.0 \pm 4.89$ & $128.0 \pm 7.34$ & $161.6 \pm 1.43$ & $143.6 \pm 1.4$ \\
\hline $\operatorname{Acidity}\left(\mathrm{mgL}^{-1}\right)$ & $30.0 \pm 2.2$ & $41.0 \pm 5.78$ & $41.0 \pm 6.78$ & $68.0 \pm 16.62$ & $47.0 \pm 12.80$ & $22.0 \pm 2.0$ & $24.0 \pm 4.0$ & $18.0 \pm 1.1$ & $12.4 \pm 1.93$ & $31.6 \pm 1.02$ & $47.8 \pm 2.74$ & $55.4 \pm 1.28$ \\
\hline Total hardness $\left(\mathrm{mgL}^{-1}\right) \mathrm{s}$ & $97.6 \pm 2.71$ & $115.0 \pm 6.32$ & $64.6 \pm 1.63$ & $56.8 \pm 1.85$ & $60.4 \pm 4.11$ & $91.6 \pm 2.71$ & $95.6 \pm 0.97$ & $112.8 \pm 3.61$ & $108.4 \pm 1.83$ & $144.6 \pm 11.86$ & $148.6 \pm 1.91$ & $135.8 \pm 0.86$ \\
\hline Ca hardness $\left(\mathrm{mgL}^{-1}\right)$ & $68.04 \pm 1.70$ & $63.82 \pm 3.07$ & $45.6 \pm 1.6$ & $50.4 \pm 1.75$ & $50.5 \pm 1.82$ & $74.78 \pm 0.84$ & $77.7 \pm 1.15$ & $82.6 \pm 0.67$ & $79.2 \pm 2.63$ & $80.72 \pm 4.24$ & $77.8 \pm 1.53$ & $75.3 \pm 0.86$ \\
\hline $\operatorname{Mg}$ hardness $\left(\mathrm{mgL}^{-1}\right)$ & $7.18 \pm 0.81$ & $12.42 \pm 0.79$ & $4.71 \pm 0.12$ & $1.16 \pm 0.51$ & $2.40 \pm 0.89$ & $4.09 \pm 0.46$ & $4.34 \pm 0.36$ & $7.48 \pm 0.68$ & $7.09 \pm 0.24$ & $15.52 \pm 1.96$ & $18.11 \pm 1.06$ & $14.56 \pm 0.26$ \\
\hline Salinity $\left(\mathrm{mgL}^{-1}\right)$ & $1.11 \pm 0.0$ & $.94 \pm 2.44$ & $2.51 \pm 0.06$ & $.82 \pm 0.02$ & $4.21 \pm 0.14$ & $3.26 \pm 0.06$ & $2.92 \pm 1.02$ & $2.51 \pm 0.01$ & $1.40 \pm 0.0$ & $2.55 \pm 0.10$ & $3.12 \pm 0.01$ & $3.02 \pm 0.24$ \\
\hline $\mathrm{BOD}\left(\mathrm{mgL}^{-1}\right)$ & $2.96 \pm 0.52$ & $5.4 \pm 0.43$ & $8.98 \pm 1.11$ & $2.82 \pm 0.46$ & $2.02 \pm 0.41$ & $4.08 \pm 0.71$ & $3.98 \pm 0.59$ & $4.06 \pm 0.41$ & $8.60 \pm 0.27$ & $8.35 \pm 0.90$ & $2.44 \pm 0.15$ & $3.14 \pm 0.11$ \\
\hline $\operatorname{COD}\left(\mathrm{mgL}^{-1}\right)$ & $5.6 \pm 0.04$ & $5.7 \pm 0.03$ & $6.64 \pm 0.12$ & $4.72 \pm 0.18$ & $9.08 \pm 1.81$ & $6.22 \pm 0.32$ & $4.4 \pm 0.12$ & $6.89 \pm 0.08$ & $7.45 \pm 0.23$ & $8.5 \pm 0.43$ & $6.38 \pm 0.12$ & $7.2 \pm 0.05$ \\
\hline $\mathrm{TDS}\left(\mathrm{mgL}^{-1}\right)$ & $782.2 \pm 8.21$ & $708.8 \pm 15.76$ & $625.6 \pm 20.82$ & $558.2 \pm 14.48$ & $702.2 \pm 17.95$ & $394.0 \pm 9.79$ & $206.0 \pm 2.44$ & $169.2 \pm 4.82$ & $127.4 \pm 2.73$ & $151.2 \pm 10.64$ & $222.2 \pm 2.72$ & $241.39 \pm 0.81$ \\
\hline $\operatorname{TSS}\left(\mathrm{mgL}^{-1}\right)$ & $144.0 \pm 16.33$ & $114.0 \pm 6.22$ & $371.2 \pm 35.63$ & $159.4 \pm 20.06$ & $199.2 \pm 6.87$ & $51.8 \pm 7.22$ & $50.2 \pm 5.60$ & $49.8 \pm 3.46$ & $24.0 \pm 0.94$ & $34.4 \pm 5.15$ & $53.8 \pm 0.97$ & $71.0 \pm 0.86$ \\
\hline $\mathrm{TS}\left(\mathrm{mgL}^{-1}\right)$ & $916.2 \pm 30.18$ & $822.8 \pm 11.06$ & $996.8 \pm 19.29$ & $717.6 \pm 19.29$ & $901.4 \pm 20.22$ & $445.1 \pm 9.09$ & $276.2 \pm 3.66$ & $213.7 \pm 2.54$ & $151.4 \pm 2.73$ & $185.6 \pm 13.76$ & $276.0 \pm 3.39$ & $313.2 \pm 0.86$ \\
\hline Nitrate $\left(\mathrm{mgL}^{-1}\right)$ & $3.3 \pm 0.43$ & $2.38 \pm 0.41$ & $5.78 \pm 1.45$ & $3.54 \pm 1.23$ & $2.42 \pm 0.56$ & $1.42 \pm 0.05$ & $1.0 \pm 0.0$ & $1.38 \pm 0.15$ & $2.76 \pm 0.26$ & $3.16 \pm 0.12$ & $2.96 \pm 0.11$ & $2.62 \pm 0.02$ \\
\hline Phosphate $\left(\mathrm{mgL}^{-1}\right)$ & $0.022 \pm 0.0$ & $0.005 \pm 0.0$ & $0.015 \pm 0.0$ & $0.005 \pm 0.0$ & $0.004 \pm 0.0$ & $0.005 \pm 0.0$ & $0.010 \pm 0.0$ & $0.009 \pm 0.0$ & $0.008 \pm 0.0$ & $0.009 \pm 0.0$ & $0.012 \pm 0.0$ & $0.016 \pm 0.0$ \\
\hline Sulphate $\left(\mathrm{mgL}^{-1}\right)$ & $18.0 \pm 1.48$ & $21.0 \pm 1.18$ & $14.6 \pm 0.51$ & $11.8 \pm 0.91$ & $7.1 \pm 0.50$ & $4.86 \pm 0.08$ & $4.18 \pm 0.18$ & $4.16 \pm 0.18$ & $4.14 \pm 0.14$ & $4.96 \pm 0.04$ & $4.14 \pm 0.06$ & $3.9 \pm 0.05$ \\
\hline
\end{tabular}




\section{Int.J.Curr.Microbiol.App.Sci (2016) 5(10): 439-450}

Table.3 Correlation (r) matrix of various physico-chemical parameters of Siliserh Lake.

\begin{tabular}{|c|c|c|c|c|c|c|c|c|c|c|c|c|c|c|c|c|c|c|c|c|}
\hline 1 & 2 & 3 & 4 & 5 & 6 & 7 & 8 & 9 & 10 & 11 & 12 & 13 & 14 & 15 & 16 & 17 & 18 & 19 & 20 & 21 \\
\hline \multirow[t]{21}{*}{1} & $-0.58^{*}$ & -0.54 & $-0.69 *$ & 0.15 & -0.20 & 0.37 & 0.10 & 0.19 & -0.30 & -0.14 & -0.02 & 0.16 & $-0.75 * *$ & -0.43 & $-0.80 * *$ & 0.01 & -0.54 & -0.06 & $\begin{array}{l}-0.03 \\
\end{array}$ & 0.25 \\
\hline & 1 & $0.97 * *$ & $0.67 *$ & -0.21 & 0.26 & 0.36 & 0.48 & 0.48 & -0.01 & $0.65^{*}$ & 0.15 & -0.28 & 0.14 & -0.38 & 0.42 & $0.63^{*}$ & 0.40 & 0.49 & -0.57 & 0.08 \\
\hline & & 1 & $0.69^{*}$ & -0.50 & $0.58^{*}$ & 0.43 & 0.48 & 0.49 & -0.05 & $0.70^{*}$ & 0.02 & -0.29 & 0.10 & $-0.82 * *$ & 0.40 & $0.70^{*}$ & 0.42 & 0.53 & $-0.72 * *$ & 0.08 \\
\hline & & & 1 & 0.07 & 0.35 & $-0.70^{*}$ & $-0.67^{*}$ & $-0.70^{*}$ & 0.45 & -0.42 & 0.07 & 0.10 & $0.87 * *$ & $0.89 * *$ & $0.69 *$ & -0.35 & 0.47 & -0.45 & \begin{tabular}{l|l}
0.52 \\
\end{tabular} & -0.13 \\
\hline & & & & 1 & 0.18 & -0.01 & -0.25 & -0.19 & 0.25 & -0.03 & 0.52 & -0.32 & 0.06 & 0.09 & 0.04 & -0.25 & -0.13 & $-0.62 *$ & 0.47 & -0.06 \\
\hline & & & & & 1 & 0.07 & -0.40 & $0-.28$ & 0.28 & -0.04 & 0.37 & 0.24 & 0.49 & 0.19 & $0.58^{*}$ & 0.51 & 0.35 & -0.21 & 0.16 & 0.49 \\
\hline & & & & & & 1 & $0.70^{*}$ & $0.84 * *$ & -0.47 & 0.40 & -0.01 & -0.16 & $-0.67 *$ & $-0.89 * *$ & -0.41 & $0.76^{*}$ & 0.19 & 0.56 & -0.56 & -0.06 \\
\hline & & & & & & & 1 & $0.97 * *$ & $-0.60 *$ & 0.38 & -0.15 & -0.30 & $-0.61 *$ & $-0.79 * *$ & -0.39 & 0.39 & 0.07 & $0.84 * *$ & $-0.67 *$ & -0.32 \\
\hline & & & & & & & & 1 & $-0.60^{*}$ & 0.42 & -0.12 & -0.28 & $-0.67 *$ & $-0.88 * *$ & -0.43 & 0.53 & 0.11 & $0.81^{* *}$ & $-0.68 *$ & -0.26 \\
\hline & & & & & & & & & 1 & -0.02 & 0.29 & -0.01 & $0.61^{*}$ & 0.51 & 0.56 & -0.20 & -0.17 & -0.53 & 0.43 & 0.42 \\
\hline & & & & & & & & & & 1 & -0.11 & $-0.59 *$ & -0.19 & $-0.59^{*}$ & 0.07 & 0.41 & -0.03 & 0.25 & $-0.61 *$ & 0.09 \\
\hline & & & & & & & & & & & 1 & 0.23 & 0.18 & 0.56 & 0.22 & 0.08 & -0.15 & -0.36 & 0.41 & 0.28 \\
\hline & & & & & & & & & & & & 1 & 0.10 & 0.22 & 0.01 & 0.06 & -0.18 & -0.03 & 0.41 & 0.24 \\
\hline & & & & & & & & & & & & & 1 & $0.80 * *$ & $0.93^{* *}$ & -0.25 & 0.24 & -0.33 & 0.50 & 0.08 \\
\hline & & & & & & & & & & & & & & 1 & 0.53 & -0.62 & 0.10 & $-0.58 *$ & $0.67^{*}$ & 0.01 \\
\hline & & & & & & & & & & & & & & & 1 & 0.01 & 0.27 & 0.31 & 0.32 & 0.11 \\
\hline & & & & & & & & & & & & & & & & 1 & 0.39 & 0.45 & $-0.60^{*}$ & 0.34 \\
\hline & & & & & & & & & & & & & & & & & 1 & 0.19 & -0.26 & -0.32 \\
\hline & & & & & & & & & & & & & & & & & & 1 & $-0.61 *$ & -0.26 \\
\hline & & & & & & & & & & & & & & & & & & & 1 & -0.72 \\
\hline & & & & & & & & & & & & & & & & & & & & 1 \\
\hline & $\begin{array}{l}\text { dicates si } \\
\text { Jater level } \\
\text { SS } \\
\text { 3OD } \\
\text { Sulphate }\end{array}$ & $\begin{array}{r}\text { gnificance } \\
\text { 2. An } \\
\text { 8.TD } \\
\text { 14. T } \\
\text { 20. D }\end{array}$ & $\begin{array}{l}\text { at } \mathrm{p}<0.0 \\
\text { hbient tem } \\
\text { otal hardn } \\
\text { issolved o }\end{array}$ & $\begin{array}{l}\text { and } * * \\
\text { perature }\end{array}$ & dicates & $\begin{array}{l}\text { significano } \\
\text { 3. Water te } \\
\text { 9. TS } \\
\text { 15. Calciu } \\
\text { 21. Free C }\end{array}$ & $\begin{array}{l}\text { e at } \mathrm{p}<0 . \\
\text { mperature } \\
\mathrm{m} \text { hardnes } \\
\mathrm{O}_{2}\end{array}$ & (1 level). & $\begin{array}{l}\text { 4. } \mathrm{pH} \\
\text { 10. } \mathrm{Al} \\
\text { 16. } \mathrm{M}\end{array}$ & $\begin{array}{l}\text { calinity } \\
\text { gnesium }\end{array}$ & hardness & & $\begin{array}{l}\text { Salinity } \\
\text {. Acidity } \\
\text { Nitrate }\end{array}$ & & $\begin{array}{l}\text { 6. Condu } \\
\text { 12. COD } \\
\text { 18. Phosp }\end{array}$ & $\begin{array}{l}\text { ctivity } \\
\text { hate }\end{array}$ & & & & \\
\hline
\end{tabular}


The study validates the fact that this freshwater lake remains oligotrophic during summer and winter but becomes loaded with nutrients during monsoon reaching eutrophic condition. Unchecked use of fertilizers has augmented the process. All the physicochemical factors studied except BOD studied were found within the permissible limit for drinking water as recommended by Bureau of Indian Standard (BIS). The lake was found to be slightly eutrophic during monsoon months. This may be due to increased nutrient load during monsoon. Nutrients and other organic matter from the agriculture fields in the catchment area are brought to the lake due to influx of rain water.

A major source of drinking water to the inhabitants may become unsuitable for potability unless definite remedial measures are taken immediately. It is clear from the present studies that the lake requires proper management strategies to minimize further degradation from the present status. For a sustainable use of the water, further anthropogenic activities in and around the lake should be controlled otherwise the lake will turn into complete eutrophic condition. poorly managed, not only at local levels but also globally.

They continue to be degraded through habitat loss due to human activities and conservation methods are urgently required to maintain the integrity and biodiversity of such ecosystems. The sustainability of Siliserh Lake ecosystem will depend upon managing the nearby agricultural setups as well as other disturbing factors. Moreover, human activities in and around the lake should be regulated. Governments must take a serious eye over the issue as it is just the beginning of the deterioration of the ecosystem.

\section{Acknowledgement}

Authors are thankful to Department of Zoology, University of Rajasthan, Jaipur for providing financial assistant in the form of Department Fellowship and laboratory facilities. We are also thankful to Inspector of Fisheries Department, Govt. of Rajasthan, Alwar, for boating facilities at Siliserh Lake.

\section{References}

Amirkolaie, A.K. 2008. Environmental impact of nutrient discharged by aquaculture waste water on the Haraz River. J. Fish. Aquat. Sci., 3: 275-279.

APHA. 2005. Standard methods for the examination of the water and waste water. $21^{\text {st }}$ ed. American Public Health Association Inc., Washington DC.

Araoye, P.A. 2007. Aspect of meteorological factors and temperature regime of Asa Lake, Ilorin Nigeria. The Zoologist, 3946.

Birge, E.A. and Juday, C. 1911. The inland lakes of Winconsin. The dissolved gases and their significance. Bull. Wis. Geol. Ne.Hist. Survey, 7: 259pp.

Chandran, R. and Ramamoorthy, K. 1984. Hydrobiological studies in the gradient zone of the Vellar estuary- nutrients. Mahasagar-Bull. Nat. Inst. Oceanogr., 17: 133-140.

Chukwu, L.O. and Odunzeh, C.C. 2006. Relative toxicity of spent lubricant oil and detergent against benthic macroinvertebrates of a West African estuarine lagoon. J. Environ. Biol., 27: 479-484.

Conides, A.J. and Parpoura, A.R. 1997. A study of oil pollution effects on the ecology of a coastal lake ecosystem. The Environmentalist, 17: 297-306.

Damotharan, P., N.V. Perumal, and Perumal, P. 2010. Seasonal variation of physicochemical characteristics of Point Calimere coastal waters (South East coast of India). Middle-East J. Sci. Res., 6(4): 333-339. 
Das, J., S.N. Das, and Sahoo, R.K. 1997. Semidiurnal variation in physicochemical parameters in the Mahanadi estuary, East Coast of India. Indian J. Mar. Sci., 26: 323-326.

Das, S.K. and Chand, B.K. 2003. Limnology and biodiversity of Icthyofauna in a pond of Southern Orrissa, India. $J$. Ectoxicol. Environ. Monitr., 13(2): 97102.

Elmaci, A., F.O. Topac, N. Ozengin, A. Teksoy, S. Kurtoglu, and Baskaya, H.S. 2008. Evaluation of physical, chemical and microbiological properties of Lake Ulubat, Turkey. J. Environ. Biol., 29: 205-210.

Garg, R.K., R.J. Rao, and Saksena, D.N. 2009. Water quality and conservation management of Ramsagar Resrvoir, Datia, Madhya Pradesh. J. Environ. Biol., 30(5): 909-916.

Gouda, R. and Panigrahy, R.C. 1996. Ecology of phytoplankton in coastal water off Gopalpur, East Coast of India. Ind. J. Mar. Sci., 2: 13-18.

Haroon, G., R.S. Khoiyangbam, S. Ahmad, and Zuber, S.M. 2010. Limnological assessment of Antiya Tal, Jhansi to assess its water quality. Int. J. Lake. River, 3(1): 79-85.

Hazelwood, D.H. and Parker, R.A. 1961. Population dynamics of some fresh water zooplankton. Ecol., 42: 266-274.

Horne, A.J. and Goldman, C.R. 1994. Limnology. $2^{\text {nd }}$ ed., McGraw Hill, Inc., New York.

Hosmani, S.P. and Bharti, S.G. 1980. Limnological studies in ponds and lakes of Dharwar. Comparative phytoplankton ecology of water bodies. Phykos, 19: 2743.

Hutchinson, G.E. 1967. A treatise on Limnology- Introduction to lake biology and the limnoplankton. Vol.II, John Wiley \& Sons, New York. 1115 pp.

Ipsen, J. and Feigl, P. 1970. Bancroft's introduction to biostatistics. $2^{\text {nd }}$ ed., Harper and Row Publishers, New York, Evanston and London.
Jana, B.B. 1973. Seasonal periodicity of plankton in a freshwater pond in West Bengal, India. Hydrobiol., 58: 127-143.

Khan, I.A. and Khan, A.A. 1985. Physical and chemical conditions in Seikha Jheelat, Aligarh. Ecol., 3: 269-274.

Khan, R.M., M.J. Jadhav, and Ustad, I.R. 2012. Physico-chemical analysis of Triveni Lake water of Amravati district in (MS) India. Biosci. Discov., 3(1): 6466.

Kinne, O., 1971. Marine Ecol., Wiley Interscience, London, 821pp.

Kumar, P. and Sharma, H.B. 2005. Physicochemical characteristics of lentic water of Radha kund (District- Mathura). Ind. J. Environ. Sci., 9(1): 21-22.

Manikannan, R., S. Asokan and Samsoor Ali, A.H.M. 2011. Seasonal variations of physico-chemical properties of the Great Vedaranyam Swamp, Point Calimere Wildlife Sanctuary, South-East coast of India. Afr. J. Environ. Sci. Tech., 5(9): 673-681.

Maulood, B.K., G.C.F. Hinton, H. S. Kamees, F.A.K. Saleh, A. A. Shaban, and Shahwani, S.M.H. 1979. An ecological survey of some aquatic ecosystems in Souther Iraq. Trop. Ecol., 20(1): 27-40.

Meena, S.L. and Sharma, K.C. 2004. Physicochemical analysis of water sediment of Panchana Dam Irrigation Project (PIP) in Karauli district, Rajasthan. Ind. J. Environ. Sci., 8(2): 121-126.

Munawar, M. 1970. Limnological studies on freshwater ponds of Hyderabad, India. II. The Biocenose, Hydrobiol., 36: 105128.

Parray, S.Y., S. Ahmad and Zubair, S.M. 2010. Limnological profile of a suburban wetland Chatlam, Kashmir. Int. J. Lake River, 3(1): 1-6.

Rajasegar, M. 2003. Physico-chemical characteristics of the Vellar estuary in relation to shrimp farming. J. Environ. Biol., 24: 95-101.

Ramakrishnan, R., P. Perumal and Santhanam, P. 1999. Spatio-temporal variations of hydrobiological features in the 
Pichavaram mangroves and Mohi aqua farm, Southeast coast of India. In: Proc.

Intl. Sem. Appl. Hydrogeochem., Annamalai University, Chidambaram, Tamil Nadu. 197-203pp.

Sakhere, V.B. and Joshi, P.K. 2002. Ecology

of Palas-Nilegaon Reservoir in Osmanabad district, Maharashtra. $J$. Aqua. Biol., 18: 17-22.

Sharma, L.L. 1980. Some limnological aspects of Udaipur waters in comparision to selected waters of Rajasthan. Ph.D. Thesis. MSL University, India.

Shashi Shekhar, T.R., B.R. Kiran, E.T. Puttaiah, Y. Shivaraj and Mahadevan, K.M. 2008. Phytoplankton as index of water quality with reference to industrial pollution. J. Environ. Biol., 29: 233-236.

Singh, S.R. 1987. Observations on the phytoplankton primary production in an Ox-bow lake. Proc. Nat. Acad. Sci. Ind., 57(B): 328-336.

Soundarapandian, P., T. Premkumar and Dinakaran, G.K. 2009. Studies on the physico-chemical characteristics and nutrients in the Uppanar estuary of Cuddalore, South East coast of India. Curr. Res. J. Biol. Sci., 1(3): 102-105.

Sreenivasan, A. 1970. Limnology studies on Parambikulamliyar Project II. Arch. Hydrobiol., 80: 70-84.

Subramanian, V. and Mahadevan, A. 1999. Seasonal and diurnal variations of hydrobiological characters of coastal waters of Chennai (Madars) Bay of Bengal. Ind. J. Mar. Sci., 28: 429-433.

Sunder, S. 1988. Ecology and pollution of
Indian Rivers. A.P.H. New Delhi.

Surve, P.R., N.E. Ambore and Pulle, J.S. 2005. Hydrobiological studies of Kandhar Dam water, district Nanded (M.S.) India. J. Ecophysiol. Occup. Hlth., 5: 71-72.

Tamot, P., R. Mishra and Saxena, A. 2007. Limnology of Halali Reservoir with reference to cage aquaculture for fish production. Proceedings of National Symposium on Limnology, Udaipur. 316-320.

Tepe, Y., A. Turkmen, E. Mutlu and Ates, A 2005. Some physicochemical characteristics of Yarrseli Lake, Hatay, Turkey. Turk. J. Fish. Aqua. Sci., 5: 3542.

Toor, H.S. and Gill, H.S. 1974. Distribution of fishes in relation to the hydrological condition of Budha Nallah. A tributary of River Sutlej, India. J. Ecol., 1: 55-62.

Trivedi, R.K. and Goel, P.K. 1992. Chemical and biological methods for water pollution studies. Environ. Pub., Karad.

Venkatasubramani, R. and Meenambal, T. 2007. Study of sub-surface water quality in Mattupalayam Taluk of Combatore district Tamil Nadu. Nat. Environ. Pollut. Tech., 6: 307-310.

Venkatesan, J. 2007. Protecting wetlands. Curr. Sci., 93: 288-290.

Vijayakumar, S.K., K. M. Rajesh, R. Mendon and Hariharan, V. 2000. Seasonal distribution and behavior of nutrients with reference to tidal rhythm in the Mulki Estuary, Southeast coast of India. J. Mar. Biol. Assoc. Ind., 42: 21-31.

\section{How to cite this article:}

Vashistha, J., P.J. John and Paulose, P.V. 2016. Water Quality Analysis of Lake Siliserh, India. Int.J.Curr.Microbiol.App.Sci. 5(10): 439-450. doi: http://dx.doi.org/10.20546/ijcmas.2016.510.050 